\title{
Cunoaşterea planului întunecat şi cunoaşterea planului vieţii în cadrul dramaturgiei răului din condacul lui Roman Melodul, La răstignirea [Domnului]
}

\author{
Ioannis KOUREMBELES*
}

\begin{abstract}
The knowledge of the dark plan and the knowledge of the plan of life within the dramaturgy of evil in the kontakion of Romanos the Melodist, At the Crucifixion [of the Lord]. The theological perspective which I develop in this study is, on the one hand, to present Christ through the power of His goodness as the supreme Good, and, on the other hand, to recall the dramatic dialogue fabric between Devil and Death in the Week of Passion with their
\end{abstract} intention declared to kill Christ.

Keywords: Romanos the Melodist, Evil, Death, Christ, kontakion, hymnography

În condacul lui Roman Melodul La răstignirea [Domnului] (Ei` $\tau \eta \dot{v} \sigma \tau \alpha v ́ \rho \omega \sigma \imath)^{1}$, pe scena teologică este prezentată drama

* Profesor universitar la Facultatea de Teologie a Universității „Aristotel” din Tesalonic (Grecia). Traducerea a fost realizată după originalul grecesc:

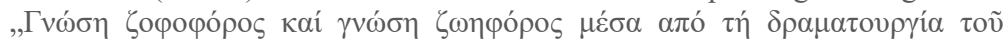

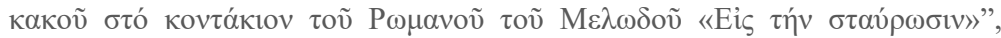

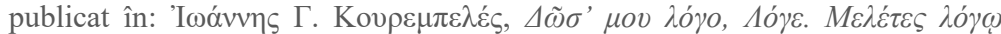

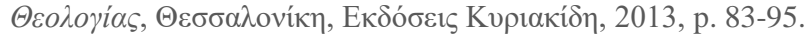

${ }^{1} \mathrm{Cu}$ privire la menţiunea mea asupra condacului lui Roman (purtând ca titlu $\mathrm{La}$ coborârea în iad în ediţia lui P. Maas-C.A. Trypanis) folosesc ediţia lui R. MaIsAno, Cantici di Romano il Melode (vol. I, Torino, 2002, p. 464-475) atât pentru indicarea strofelor, cât şi pentru versuri. În analiza [studiului] cităm ca atare, între ghilimele, versurile dramatice ale lui Roman, iar în italic propria mea traducere ale acestor versuri. Cititorul care doreşte şi o altă redare a imnelor [romaneice] în limba neogreacă poate să consulte încercarea preţioasă 
mântuirii omeneşti. În prooimionul „Suflete al meu, suflete al meu,

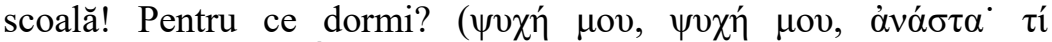
$\left.\kappa \alpha \theta \varepsilon v ́ \delta \varepsilon ı \varsigma_{;}\right)$, poetul Îl pune în avanscenă pe Hristos, identificat cu Dumnezeu-Cuvântul, iar în prima strofă prezintă „cămara” cea

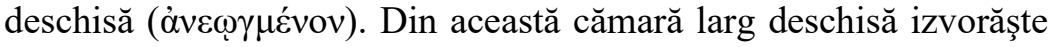
vindecarea lui Adam, iar diavolul, rănit şi simţind mai cu seamă primejdia [adusă] de Hristos, Tămăduitorul cel fără de plată, ,se

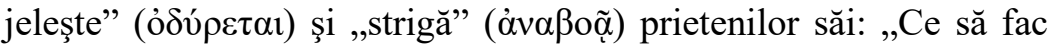
Fiului Mariei? Mă ucide Cel din Betleem, Cel ce pretutindeni este

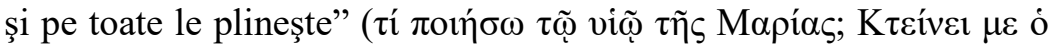

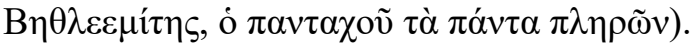

Hristos Cel binefăcător este prezentat, deci, de la început ca Fiul Mariei, Care este însă în esenţă ,,pretutindeni şi pe toate le

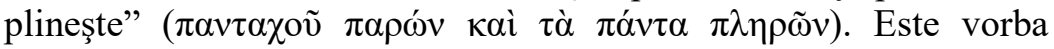
despre o prezentare paradoxală a lui Dumnezeu-Cuvântul, care este pentru noi un mod de exprimare familiar din cunoscutul refren al condacului la naşterea lui Hristos: „Prunc tânăr, Dumnezeu Cel

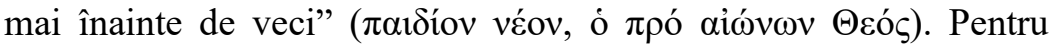
teologul-poet este important să consemneze identitatea dumnezeiască a lui Hristos, fiindcă numai aceasta garantează o tămăduire fără de plată. În acest context de exprimare, la nivel ontologic, binefacerea este considerată că poate fi realizată în afara termenilor de schimb numai de către Cel care este El Însuşi binele şi care-i cheamă pe oameni la faptele cele bune.

\section{Lumea s-a umplut de minunile Sale}

Ceea ce îl doare pe demon mai înainte de toate este sentimentul determinării de sine a lui Hristos pentru tămăduirea

a imnelor lui Roman făcută de arhim. Ananias KouSTENIS ("Y $\mu v o \imath$ P $\omega \mu \alpha v o \tilde{v}$

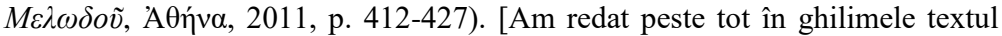
romaneic şi nu am optat pentru versiunea autorului de a indica strofele şi versetele romaneice prin cifre arabe. Pentru ediţia în limba română am folosit: Sfântul Roman MElodul, Imnele Sfintei Scripturi, studiu introductiv, traducere şi note de Alexandru Prelipcean şi Alexandru Iorga (Patristica. Traduceri, 4), Iaşi, Edit. Doxologia, 2012, p. 289-297 (n.trad.)]. 
lumii, pentru realitatea că lumea întreagă s-a umplut de minunile Sale. Simte, desigur, o durere adâncă din cauza înştiinţării

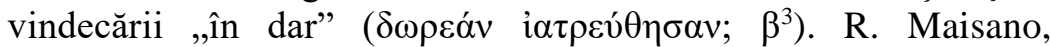
editorul şi traducătorul în limba italiană a condacelor lui Roman, uneşte, nu lipsit de sens, imaginea cămării celei deschise cu cea a mormântului deschis ${ }^{2}$. În mod evident, poetul pune într-o relaţie apropiată (cu sens figurat, desigur) vindecarea în dar mai înainte de Înviere şi vindecarea în dar a umanităţii din prisma evenimentului Învierii lui Hristos.

Desigur, precum minunile concrete care sunt menţionate în

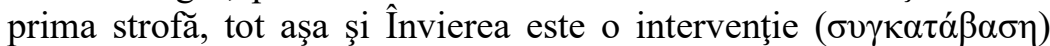
vindecătoare, oferită în dar de Dumnezeu, în istoria omenească. Hristosul lui Roman, aşa cum accentuează [imnograful] în mod intenţionat prin refrenul poeziei, este ,pretutindeni prezent şi Care

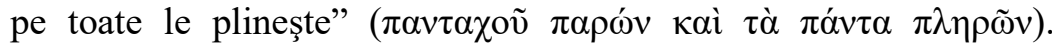
Referirea lui Roman asupra existenţei mântuirii în dar şi relaţia acesteia cu terminologia medicală, indică semnnificaţia calitativă a mântuirii omului în firea sa stricată prin Însuşi Creatorul său şi reacţia Melodului asupra consideraţiei cantitative a vindecării omului prin termenii de schimb şi reducere în căderea morală.

\section{Lumea întreagă plină de drame demonice şi de cuvinte}

În strofa a treia demonul strigă pe cei ai săi, pe ,prietenii

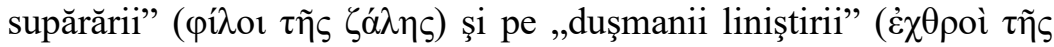
$\gamma \alpha \lambda \eta ் v \eta$ ) şi le cere sfatul lor: „Ce să fac cu Hristos?”. Ei îi spun:

„Daţi vreun gând minţii mele!

$\mathrm{Cu}$ adevărat $\mathrm{m}$-am încurcat şi pierdut mă simt, nimic nu-mi amintesc şi [nimic] nu pot;

m-am năucit, întunecatu-mi-s-a mintea.

Pe neaşteptate $\mathrm{m}$-a tulburat

Cel ce pretutindeni este şi toate le plineşte".

${ }^{2}$ R. Maisano, Cantici, I, p. 465, nota 2. 
Cei ai săi, prietenii înşelătorului, încearcă să îi ofere curaj şi îi spun:
„Veliar, nu te-nspăimânta!
Prinde curaj [şi] păstrează-ţi bine mintea!
De mai vechile tale izbânzi aminteşte-ţi!
Cele ce în Paradis s-au petrecut, înnoieşte-le!
De vei îngreuna iarăşi umerii urmaşilor lui Cain
precum [a făcut-o] Abel, cu viclenie se vor pierde".

Şi în strofa următoare, în mod reprezentativ, Roman îi lasă pe cei vicleni să-1 sfătuiască pe demon şi să-1 încurajeze, spunând că lumea este plină de urmaşii lui Cain şi că acolo sunt încă preoţii şi cărturarii, Iuda şi Caiafa. Îi spun să nu se descurajeze ca şi cum nu ar mai avea prieteni în lume, de vreme ce Irod este prietenul său înflăcărat, iar Pilat îl va sluji. Îi spun să nu plângă, de vreme ce ,de faptele [sale] cele multe plin este întreg pământul"'3. Îl confirmă,

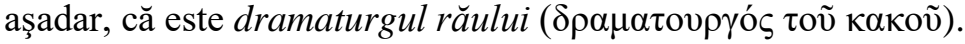

Diavolul primeşte, desigur, cu bucurie cuvintele sfătuitorilor săi şi comunică mai apoi mulţumit ajutorul său pentru iudei, învăţându-i să spună [pentru Hristos] „Să se răstignească” $\left(\sigma \tau \alpha \nu \rho \omega \theta \eta \dot{\tau} \tau \omega ; \zeta^{7}\right)$. Îi subordonează în mod real faptei celei rele a sa şi, aşa cum poetul îl prezintă, diavolul se apropie de sinedriul iudaic şi de opozanţii lui Hristos, inspirându-le hotărârea pentru pătimirea Sa care va veni.

Aici Roman foloseşte frumoasa exprimare „,noaptea nopţii

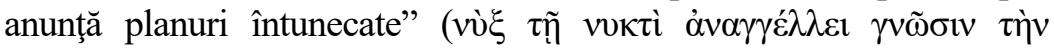

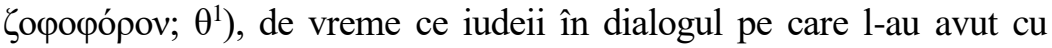
demonul, îl uşurează de grija şi intenţia sa cea rea, confirmându-i: „Lasă grija ta! Cele pe care tu le poţi face, noi le-am împlinit. Nu te îngriji de nimic, rămâi liniştit! Predatu-s-a Iisus şi L-au tăgăduit! Legat a fost şi la Pilat a fost dus" $\left(\theta^{4-7}\right)$. Cunoaşterea, care este precum planul cel întunecat, propune ca exprimare, în opinia mea, căutarea interioară de către creş̧inul participant la slujbe a cunoaşterii planului vieţii pe care-1 indică Hristos ca Persoană dumnezeiească.

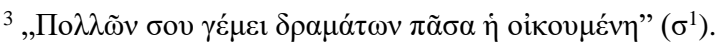


Aici cuvântul îl au puterile demonice, care colaborează cu iudeii; aceştia încep să dialogheze cu cel rău, care le răspunde că nu îi consideră nepăsători şi din acest motiv a venit să-i ajute. Ei înşişi au desăvârşit ceea ce trebuia să finalizeze cel rău. Diavolul clarifică, aşadar, opinia că cei ai lui se arată grăbiţi în înfăptuirea acestor fapte. Iudeii îl depăşesc pe cel din vechime rău, sprijinind răul. Demonul însuşi le reaminteşte primele rele pe care le-au făcut, atunci când au mâncat mană (Ieş. 16:1 sq.) şi au băut lapte (Dt. 31:20 şi 32:13-15) ${ }^{4}$, tăgăduindu-L pe Dumnezeu şi ajungând la minciună. De altfel, ei au fost cei care au preferat viţelul de aur în locul lui Dumnezeu (Ieş. 32:1).

Analiza psihografică pe care Roman o întreprinde în poemul său dramatic, îl face cunoscut pe creatorul care-l descrie pe omul demonic şi, bineînţeles, nu doar pe iudeul care este adus în avanscenă. Aici diavolul ,face o apologie” pentru armata sa (strofa 11), care este împotriva lui Hristos. Le spune [iudeilor] că ei sunt

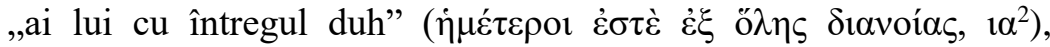
aşadar cu toată raţiunea lor. Le aminteşte că-1 urăsc doar „,cu gura” ( $\left.\tau \tilde{\omega} \sigma \tau o ́ \mu \alpha \tau \imath ; 1 \alpha^{3}\right)^{5}$, aşadar doar cu cuvintele, lucru care-1 bucură. Îi fericeşte că acest comportament creează o schismă, o ruptură, prin intermediul căreia pe mulţi $\hat{\imath} i$ va supune. În timp ce demonul este prezentat a fi urât de către cei ai lui doar prin cuvinte, Hristos (,Cel ce pretutindeni este şi pe toate le plineşte", după cum repetă refrenul) este urât şi prigonit prin fapte, deci, în mod real.

Demonul îi încurajează pe cei ai săi să nu ,strângă cu putere” cuvintele lui Moise, pe care le ,deţin” în mintea lor. Accentuează aşadar, ca în ,gură să le aibă, dar nu şi în suflet" (înţeleg cuvintele lui Moise) şi îi îndeamnă să ţină cărţile [sfinte] doar în mâini, însă cu duhul să nu le atingă şi să nu le pună, deci, în inima lor ${ }^{6}$. Îi doreşte ,cititori şi nu cunoscători ai Scripturilor” $\left(1 \beta^{6}\right)$.

\footnotetext{
${ }^{4}$ Aici R. MAISANO consideră că poate fi subînţeleasă de către poet şi dumnezeiască învăţătură (I Cor. 3:2 şi Evr. 5:12).

${ }^{5}$ Vezi şi Ps. 77:36.

6 Explicaţia suplimentară o preiau din traducerea în limba italiană a lui R. MAISANO: ,... tra le mani tenete la Bibbia ma con il coure non la sfiorate neppure" (Cantica I, p. 471).
} 
Prin aceste cuvinte, cel rău îi sprijină pe cei lipsiţi de lege

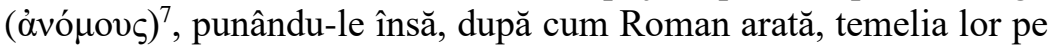
nisip. S-a mişcat mai apoi să o trezească chiar şi pe Moarte, spunându-i: „Ridică-te şi de cele ce-ţi voi spune te vei bucura! S-a predat Iisus şi de El s-au lepădat; legat a fost şi la Pilat a fost dus" $\left(1 \gamma^{4-10}\right)$. Începe aici un dialog alert cu Moartea în jurul Persoanei lui Hristos cu o semnificaţie teologică aparte.

\section{Demonul [vorbeşte] Morţii: dialogul întunericului}

Moartea, bucurându-se, vede pe diavol că se apropie, însă ea este stăpânită de o durere sfâşietoare. Prin exprimarea ,,pe mine mă

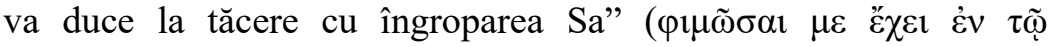
$\left.\theta \alpha ́ \pi \tau \varepsilon \sigma \theta \alpha 1 ; 1 \delta^{5}\right)$ indică pentru ea însăşi cât o costă (şi cât o va costa) tăcerea lui Hristos în faţa lui Pilat. Moartea cea rea se teme de această tăcere a lui Hristos înaintea puterii lumeşti, aşadar înaintea falsei puteri, şi din acest motiv spune că, dacă lui Pilat nu i-a vorbit, atunci El plănuieşte să clatine cele de jos, să arunce, deci, iadul la pământ $\left(1 \delta^{6-7}\right)$.

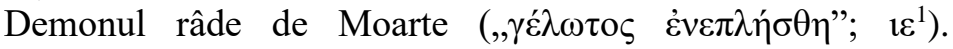
Găseşte comportamentul ei lipsit de curaj şi îi aminteşte [fapte] care nu cred că ar oferi curaj unui [personaj] deja timid:
„Acum am înţeles că eşti nemernică şi laşă din întâmplarea cea cu Lazăr
şi a multor altora pe care i-ai pierdut,
căci te înspăimântezi chiar şi de numele lui Iisus
şi slugă umilă te are
Cel care pretutindeni este şi toate le plineşte".

Diavolul, deci, îi aminteşte de morţii pe care Hristos i-a luat în mâinile Sale şi în mod real, prin cele pe care i le spune, arată el

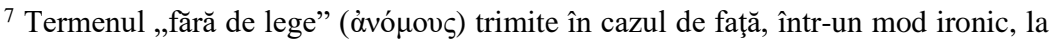
aluzia care s-a făcut în strofa precedentă, unde demonul le-a spus iudeilor: „Văd că purtaţi cuvintele Legii lui Moise”.
} 
însuşi neputinţa, amplificând poate şi mai mult lipsa de curaj a interlocutorului său.

În strofa următoare, Moartea în mod caracteristic îi răspunde că: „Acum mă ocărăşti şi-mi spui această vorbă, o, diavole, dar eu mai mult pe tine te-am văzut; să te sperii şi să te cutremuri. Am simţit cum te-ai zguduit şi cum ai tremurat" $\left(1 \varsigma^{1-3}\right)$. Îl întreabă, deci, în versurile următoare: „Nu din morminte (înţeleg pe Hristos) te-a alungat (Mt. 8:28)? Nu te-a depărtat de a cananeencei fiică, iar altă dată de cel surd şi mut (Mc. 9:14-29)"’?

În acest dialog dramatic unul către altul îşi mărturisesc experienţele lor amare din pricina întâlnirii şi încercărilor lor cu Hristos Cel binefăcător. Înţeleg, aşadar, neputinţa lor în faţa Lui. Cu toate că demonul indică [Morţii] să nu treacă cu vederea acestea (,nu trec cu vederea ceea ce spui; o ştiu chiar de nu vreau, că Hristos este în fire biruitor" $\left.; \zeta^{1-2}\right)$, totuşi este încăpăţânat şi „nu renunţă la luptă". Face cunoscută [realitatea] că a pregătit groapa şi că, dacă [Hristos] scapă, el va fi ruşinat. La fel trebuie să-şi arate [puterea] şi iudeii $\left(1 \zeta^{4-7}\right)$.

Aici este vorba despre încăpăţânarea împotrivirii demonice şi opoziţia iubirii dumnezeieşti, gratuite şi vindecătoare, pe care Roman o indică auditoriului său în mod evident şi prin ţinta şi perspectiva sa pastorală. În mod sigur, el doreşte să arate dimensiunea tragică a luptei împotriva lui Dumnezeu în viaţa demonului căzut, dar şi a omului care trăieşte şi înţelege vindecarea numai prin prisma termenilor de schimb şi al interesului egoist.

Cel viclean, după cum Moartea îl numeşte pe diavol $\left(\pi \circ \lambda v \mu \eta \dot{\chi} \alpha v \varepsilon ; 1 \theta^{3}\right)$, se pregăteşte, deci, să meargă spre iudei, către cei care împărtăşesc aceeaşi îndrăzneală şi [împreună] să se opună Celui din Betleem, ,purtând a lor necuviinţă ca o platoşă" ( $\tau$ ̀̀v

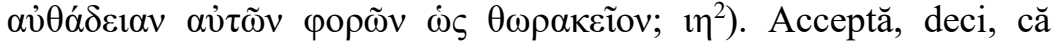

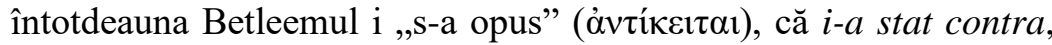
cum ar spune astăzi limbajul profan. Acceptă că [Acel] Copil din

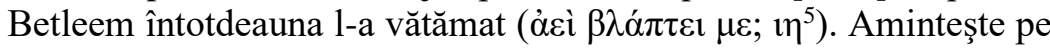
David şi fuga sa din pricina acestuia şi a urmaşilor săi (II Sam.

8 Despre înţelesul dogmatic al exprimării acesteia vezi: І.Г. КОҮРЕмПЕ $\Lambda$ Е,

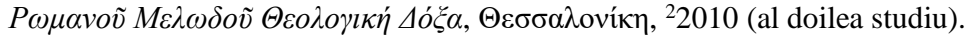


23:14-17) ${ }^{9}$. Moartea nu va fugi spre iudei, ci-1 va lăsa pe cel rău să meargă către cei răi $\left(\mathrm{l}^{1}\right)$, spunând diavolului cu tonul ridicat că nu împărtăşeşte îndrăzneala acestuia. Îi accentuează că numai ,dacă va

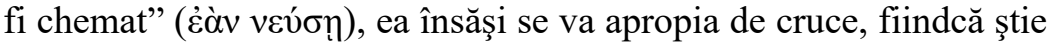
că ,de [Hristos] nu vrea, nu moare” $\left(1 \theta^{6-7}\right)$.

După cum am arătat mai sus, demonul acceptă faptul că „Hristos Cel neînvins în fire este biruit”, acceptând, aşadar, adevărul teologic al enipostazierii firii umane în Însuşi Dumnezeu. Şi Moartea accentuează aici un alt adevăr dogmatic important care este în aceeaşi perspectivă cu cele de mai sus, şi anume că Hristos nu pătimeşte silit [fiind], ca şi cum ar fi un simplu om, ci pătimeşte, dorind [pătimirea] în trupul Său, de vreme ce în dumnezeirea Sa, aşadar ca Dumnezeu, El este nepătimitor. Prin toate cele spuse se confirmă credinţa Bisericii, pe care Roman o evidenţiază într-un mod creator şi nu prin intermediul chipurilor sfinte, ci prin puterile întunericului care ajung să experieze ipostasul dumnezeiesc al lui Hristos.

Prin urmare, poetul creator plăsmuieşte poemul său dramatic nu pentru delectarea simţirilor prin cuvânt şi melodie, ci ca să expună într-un mod reprezentativ credinţa bisericească, care se opunea modului eretic de gândire al epocii sale.

\section{Lemnul crucii sau cum

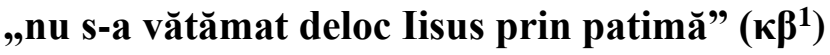

De vreme ce diavolul a constatat frica Morţii, prietenul său, a mers la iudei, găsind la ei ceea ce căuta. Într-adevăr, aceştia L-au dus [pe Hristos] înaintea celor care L-au batjocorit, L-au biciuit şi i-au arătat [diavolului] că Cel care făcuse atâta zgomot este acum ,întins cu mâinile pe lemn" $\left(\kappa^{7}\right)$. I-au spus din nou că se va bucura ca un tânăr când va auzi că unul dintre tâlharii care a fost răstignit cu Hristos L-a

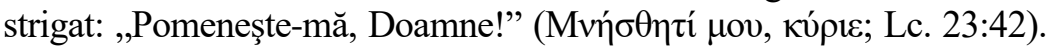

${ }^{9}$ Este evident aici că Roman uneşte, prin intermediul prezenţei Cuvântului (ca fără de trup, prin modelul lui David, şi cu trup, prin prezenţa trupească în faţa morţii), Vechiul Testament de cel Nou. 


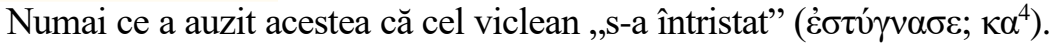
I-a părut rău atât de mult, încât capul şi 1-a plecat, strigând: „Dacă pe

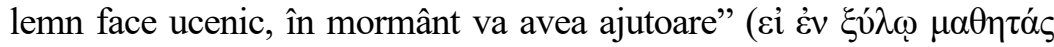

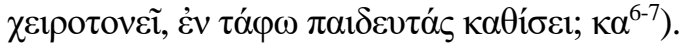

Cel de la început rău acceptă, deci, în strofa 22 că „,Iisus nu s-

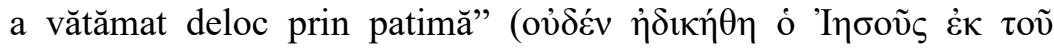
$\pi \alpha \dot{\theta} \theta$ ov $\left.; \kappa \beta^{1}\right)$. Cât despre sine însuşi... s-au înmulţit bocetele în sinea sa. Îşi aduce aminte de Moarte, prietenul său, luând în consideraţie bunul ei sfat pe care i l-a dat mai înainte de a se confrunta cu Hristos ,cel nebiruit”. Ii cere Morţii să-1 compătimească şi să-1 ia acolo jos cu ea, să-1, ,pedepsească”, de vreme ce nu mai poate să sufere ruşinea cea mare, pe care a primit-o de la lemnul (crucii) prin intermediul lui Hristos.

\section{Concluzie}

Roman obişnuieşte să termine poemele sale într-o perspectivă doxologică. Aici finalul poemului său are un caracter didactic. Declară în mod caracteristic, prin cele pe care le-am văzut, că ,cei nelegiuiţi, fără de voia lor [chiar]" învaţă că Mântuitorul tuturor oamenilor, desigur, al celor care cred [în El], ,pe cruce de bunăvoie S-a răstignit" $\left(\kappa \gamma^{1-3}\right)$. Aduce ca dovadă, desigur, realitatea că lui Hristos nu I S-au ,zdrobit” picioarele, precum celor doi tâlhari de lângă El (Mt. 27:50), realitate care învaţă că Hristos „,nu a murit fără de voie”, ci „duhul de bună-voie 1-a lăsat să plece” $\left(\kappa \gamma^{5-7}\right)$.

Prin urmare, ținta Melodului melozilor a fost să creeze, prin intermediul acţiunii dramatice a condacului său, condiţiile [prielnice], astfel încât la nivel dialogal să se menţioneze acest adevăr dogmatic important de mai sus, care-L prezintă pe Hristos prin puterea bunătăţii Sale ca Binele suprem şi demonstrează în esenţă răul demonic ca fiind slab.

Foloseşte în mod deliberat în poemul acesta dialogul cu protagonişti ce au chipurile întunecate ale diavolului şi ale morţii, dar care totuşi luminează adevărul despre Persoana lui Hristos Cel binevoitor, a Celui care, prin Învierea $\mathrm{Sa}$, aminteşte întregii umanităţi viaţa reală. 


\section{Bibliografie}

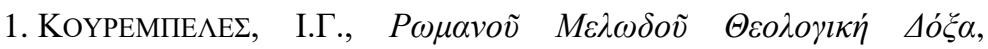

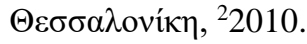

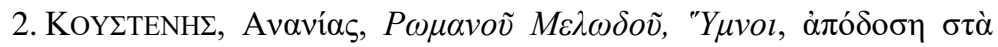

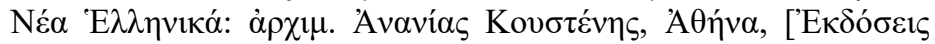

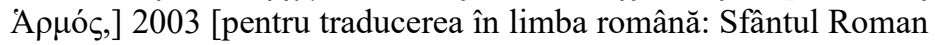
Melodul, Imnele Sfintei Scripturi, studiu introductiv, traducere şi note de Alexandru Prelipcean şi Alexandru Iorga (Patristica. Traduceri, 4), Iaşi, Edit. Doxologia, 2012, p. 289-297].

3. Maisano, R., Cantici di Romano il Melode, vol. I, Torino, 2002.

(traducere din neo-greacă de Alexandru Prelipcean) 